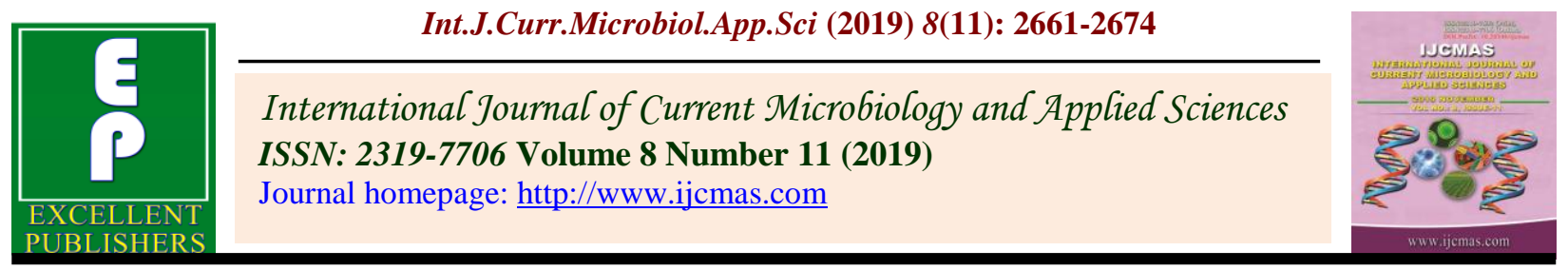

Original Research Article

https://doi.org/10.20546/ijcmas.2019.811.305

\title{
Instability and Growth Rate Analysis of Investments done by NABARD in the Watershed Development Sector of India
}

\author{
S. Lokesh* and P. Indira Devi \\ Department of Agricultural Economics, College of Horticulture, Kerala Agricultural \\ University, Thrissur-686 656, India \\ *Corresponding author
}

\section{A B S T R A C T}

Keywords

NABARD,

Watershed, Funds,

Grants, Soil and

Water Conservation

Article Info

Accepted:

28 October 2019

Available Online:

10 November 2019
Climate change is the burning issue that is getting severe every year, it has affected the condition of the many countries with an increased number of droughts, floods, and other calamities. Particularly in developing countries like India, climate change has the highest impact with a greater number of droughts, which affects the food production, livelihood and nutritional security of the rural people. It is also disturbing the economic condition of the country, to overcome these GoI has taken many initiatives, once among is developing the watersheds in the dry land areas. In this regard, NABARD took the initiation and funded many watershed and soil and water conservation works in the country. The present study tried to through light funds advanced by the NABARD for watershed development in the country over the years. Trend and Instability were used in the study for analyzing the growth rate and stability in the movement funds.

\section{Introduction}

Climate in a narrow sense is the "average weather," or more rigorously, as the statistical description in terms of the mean and variability of relevant quantities over a period of time ranging from months to thousands of years (IPCC, 2014). Climate plays a vital role in agriculture production with periodical climate variations viz., precipitation, temperature, solar radiation, soil moisture and etc (Vining, 1990). For example, the climatic factors like temperature has a prominent role in rice production, the optimum temperature for rice production is $26-28{ }^{\circ} \mathrm{C}$ at vegetative stage and $22-27{ }^{\circ} \mathrm{C}$ in grain filling stage, divergence in temperature from its normal could lead to yield losses (Deng et al., 2015). Similarly, variation in solar radiation from its normal could decrease the biomass and grain yield in rice (Vijayalakshmi et al., 1991). Among the various climatic factors, rainfall 
has a direct relationship with agricultural production since, it affects area sown, soil moisture, net area irrigated, indirectly affects the temperature and etc. Prasanna (2014) has developed indices for rainfall and crop production, which shows there is a strong relationship between rainfall and crop production. Tirlapur et al.,(2015) showed that area sown strongly depends on rainfall in Northern Karnataka and cropping pattern has changed in the study area because of variation in the rainfall.

Rainfall aberrations are increasing in the country from the past few decades around the globe and in India. Lal (2003) showed that the country will observe a decline in rainfall by 5 and $25 \%$ rainfall in winter and summer. Upper Gangetic plains in India have experienced annual deficiency of about $205.3 \mathrm{~mm}$ rainfall during 1986-2015. In Kharif (June-September) season has observed an annual deficit of 196.3 $\mathrm{mm}$ rainfall particularly, July $(52.80 \mathrm{~mm})$, August $(84.20 \mathrm{~mm})$ and September $(54.00 \mathrm{~mm})$ months faced severe moisture deficit (Verma et al., 2018). Increased in the number of drought years was panicking because, it was drastically affected both humans and livestock by reducing the crop and fodder production (Zhang et al., 2017).Similarly, Karnataka has also faced an increase in the number of drought years in the past two decades. Drought has managed to reduce the area cultivated by 30 per cent in 2014 (Lokesh and Poddar, 2018), which reduced the crop production by 80 per cent in later stages (Lokesh and Poddar, 2016). Similarly, drought has managed to reduce crop production by 60 per cent in Maharashtra (Udmale et al., 2014). Apart from crop loss, drought situations also affected farmers livelihoods very badly (Rossi and Castiglione, 2011; Udmale et al., 2014). Government of India has launched many programmes viz., National Watershed Development Project for Rainfed Areas (NWDPRA), Watershed Development in
Shifting Cultivation Areas (WDSCA), Drought Prone Areas Programme (DPAP), Desert Development Programme (DDP), Integrated Wasteland Development Project (IWDP), Pradhan Mantri Krishi Sinchayee Yojana (PMKSY) etc. in order to overcome these drought situations and to reduce the crop failures in the recent past. NABARD has given the responsibility of funding these projects apart from financing other agricultural and rural developing activities.

Apart from own funds, NABARD was successful in collecting the funds from different International agencies like Kreditanstaltfür Wiederaufbau (KFW) Germany also from the Government of India. Hence, the present study aims at analysing the sources of funds collected by NABARD for different watershed development projects implemented in different parts of the country and to analyse the funds released to the different watershed projects by the same.

\section{Materials and Methods}

Study has been carried out on a top-bottom approach, India the on the macro level and it mainly concentrated on credit flow to the watershed development by the NABARD which is a central bank for agriculture concerned. Annual reports of the NABARD have been collected from 1983 to 2018 and data regarding credit advanced thorough different schemes was extracted from 1992-93 to 2017-18. Collected data were analysed with average, percentages, Instability analysis and Compound Annual Growth Rate (CAGR).

For computing compound growth, the exponential function of the following form was used.

$\mathrm{Y}=\mathrm{a} \mathrm{b}^{\mathrm{t}} \mathrm{e}^{\mathrm{Ut}}$

Where, 
$\mathrm{Y}=$ Grant received/advances given. $(\mathrm{a}=$ Intercept, $b=$ Regression coefficient (' $a$ ' and ' $b$ ' are the parameters to be estimated)

$\mathrm{Ut}=$ Disturbance term in year ' $\mathrm{t}$ '

The equation (1) was transformed into log linear form and written as;

$\log \mathrm{Y}=\log \mathrm{a}+\mathrm{t} \log \mathrm{b}+\mathrm{Ut}$

Equation (2) was estimated by using Ordinary Least Squares (OLS) technique.

Compound growth rate (g) was then computed

$\mathrm{g}=(\mathrm{b}-1) 100$

Where,

g: Compound growth rate in per cent per annum

b: Antilog of $\log b$

The standard error of the growth rate was estimated and tested for its significance with ' $t$ ' statistic.

\section{Instability Index analysis}

The coefficient of variation was used as a measure to study the variability fund flow to the watershed development sector. The coefficient of variation or index of instability was computed by using the following formula

$$
C V=\frac{\text { Standard Deviation }(\sigma)}{\operatorname{Mean}(\bar{X})} \times 100
$$

Linear trends were fitted to the original data of funds flow for a different period for different projects. The trend coefficients were tested for their significance. Whenever the trend of series found to be significant; the variation around the trend rather than the variation around mean was used as an index of instability. The formula suggested by Cuddy and Della (1978) was used to compute the degree of variation around the trend. That is the Coefficient of variation was multiplied by the square root of the difference between the unity and coefficient of multiple determinations $\left(\mathrm{r}^{2}\right)$ in the cases where $\mathrm{r}^{2}$ was significant to obtain the Instability Index.

\section{Instability Index}

$$
=\frac{\text { Standard Deviation }(\sigma)}{\operatorname{Mean}(\bar{X})} \times 100 \times \sqrt{1-r^{2}}
$$

\section{Results and Discussion}

In the earlier seventies, in order to enhance the productivity of dry lands and to increase food production programmes like Drought Prone Area Programme (DPAP) and Desert Development Programme were introduced by Government of India. Success of these programmes has led to the creation of the National Watershed Development Project for Rainfed Areas (NWDPRA) during the seventh five-year plan. On the other hand, NABARD took an initiative to fund the implementation of watershed works in alliance with an International German bank called Kreditanstaltfür Wiederaufbau (KfW). KfW and NABARD has started funding these works since 1992-93, after the success of the first phase works, the German Government also took part in the initiative of combating the climate changes in India.

NABARD has received about 2810.46 crore rupees since from 1992-93 to 2017-18 for watershed development works (Table 1). On average the bank has received Rs. 108.09.71 crore grants per year from different International institutes, Governments and transfers from bank's profit and loss account. Highest grant of Rs. 933.82 crore was 
received in 2010-11 and the grants received was increased at the rate of 15.49 per cent annually in the study in the period. Instability analysis showed that the grants received by the banks are highly volatile (183.47\%).From the grants received, the bank has advanced the Rs. 2436.46 crores (83.04 per cent) to the said purpose in the study period. Average amount lent was 93.71 crore per year and it has observed 35.12 per cent growth over the years and lending was less volatile(162.92 per cent) compared to the grants received.

Triennium analysis was carried out with respect to identify the trend in the receipt and advances issued. Both amounts received and advanced followed the increasing trend till 2009-10 and from 2012-13 started declining (Fig 1). Triennium also confirms that the grants received was varied compared to advances inclined. The increasing trends might be due to the severe droughts faced by the country in the years viz., 2002, 2004, 2009, 2014, 2015.

Table 2 represents the total funds obtained by NABARD from KfW Germany and the German Government. A sum of 402.63 crore rupees to was obtained between 1992-93 to 2017-18. Fund was received at the rate of 15.49 crore per year, followed the growth rate of 10.24 per annum and the amount received was volatile $(85.98 \%)$ over the study period.

NABARD has obtained grants from the KfW German Bank for the watershed works in India. Table 3depicts the data on the Nation's first watershed development project by NABARD that was implemented from 199293, was aided by KfW, Germany. KfW advanced a sum of Rs. 110.48 crores as a gift to combat the climate changes in India and to uplift the rural livelihood. Funds flow has started in 1992-93 and stopped in 2007-08, the project received annual funds of Rs. 6.91 crore of which 93.63 crores was advanced by the
NABARD. On an average 5.18 crore rupees was spent every year for developing 10 watersheds in total, covering an area of around 1000 ha. Grants received was increased at the rate of 3.08 per cent over the years. Nearly $1 / 2$ of the money was released between 1999-00 and 2001-02. Similar observations were Kotru (2003).

After witnessing the success of KfW funded watershed projects, Government of India showed interest towards creation of Watershed Development Fund (WDF) desperately for watershed development. It has deposited 200 crores (100 crore each by both GoI, and NABARD) and made NABARD as the central authority to manage the funds.

The programme was aimed at developing watershed in 100 districts from 17 states, in the first phase Andhra Pradesh (06), Gujarat (9), Orissa (6), Himachal Pradesh (10), Karnataka (17) Maharashtra (8) and Rajasthan (10) were covered. Table 4 represents the flow of funds to the Watershed Development Works from the NABARD.

The project was started with the 200crorebudget, later GOI and NABRD both contributed often to the fund, till 2017-18 project received a sum of Rs. 18602.40 crore. Apart from initial contribution, NABARD has made a special contribution 1398.27 crore rupees from its profit and loss account between the years 2008 to 2011 because of the positive effect of the watershed works in the rural areas of the country. Funds given for the Watershed Development was increased at the rate of 11.58 per annum and it was comparatively stable (41.88\%). 1972.17 cores rupees was released for the works till 2017-18, and highest (Rs. 852.89 crores) amount was spent in 2013-14.Advances given under the project was increased at the rate of 39.77 per cent whereas it was highly volatile (134.33\%). The table depicts that watershed development 
works progressed from 2010-11 it may be because of the severe drought situation in major parts of the country in the previous decade.

With the increasing climate change effects viz., deterioration of natural recourses and increase of poverty ratio in the rural parts of India were observed. To curb these effects Government of Germany has contributed some grants to India, with the aim of treating nearly 3 lakh ha of dry land area. It was aimed to develop 300 watersheds in the States viz., Andhra Pradesh (Undivided), Maharashtra, Gujarath and Rajasthan. The Project has been named as "The Indo German Watershed Development Programme (IGWDP).

The Indo German Watershed Development Programme - Andhra Pradesh (IGWDP-AP) was a similar programme implemented by NABARD in collaboration with German Government, to rehabilitate the degraded watersheds in the districts of Adilabad, Karimnagar, Warangal and Medak of Telangana (earlier Andhra Pradesh). Table 5 represents the grants flow to the IGWDP programme in Andhra Pradesh, it has started in 2003-04 with an initial contribution of 0.58 crores and till 2016-17 a sum of Rs 57.12 crore was endorsed to the state. The average amount sanctioned per year was around Rs. 4.08 crore and the average amount spent was 3.97 crores. Amount sanctioned was increased at the rate of 19.55 per cent and the stability of the funds' flow was very low (78.23). Scheme has expended around 55.59 crore rupees over the years and 78.5 per cent of the money was spent in the span of 5 years which was due to the severity of drought in Andhara Pradesh during those days.

The next phase of Indo German Watershed Development Programme has started in Maharashtra. The programme started from the
2005-06 and was continued up to 2016-17 (Table 6). Maharashtra received around Rs. 122.16 crore rupees with an average of 15.27 crore per year. Amount reception was comparatively stable and was increased at the rate of 33.27 per cent per year. Reception of fund was stopped in 2012-13 because of the completion of the projects, whereas advances continued till 2016-17 because of the capacity building and follow-up activities conducted in later stages.

Indo German Watershed Development Programme has sponsored $3^{\text {rd }}$ phase activities in Gujarat from 2006-07 and is still operating (Table 7). Overall 41.60 crore rupees was provided to the state through the IGWDP project with an average of 3.42 crores per year. The project started with an initial amount of Rs. 0.37 crores and a major portion was credited during 2011-2016 around 79.10 per cent of the money was credited in this period. Credit received was increased at the rate of 11.64 per cent per year and the contribution was volatile $(74.65 \%)$ over the years.

Rajasthan is the last state to get IGWD programme in India. Programme was initiated in 2007-08 and is still continued (Table 8). The State got around 42.13 crore rupees from 2007-08 to 2017-18 with an average annual contribution of 3.83 crore rupees per year. Expenditure made was highest $(23.04 \%)$ in the 2014-15 and about 68.37 per cent of the amount was released between 2011-2018.

Rashtriya Sam Vikasa Yojana (RSVY) is a scheme initiated for development of backward districts by the Central Government. Scheme was started with the aim of covering 100 backward districts in the country. The scheme was launched in 2004-05 (Table 9), NABARD has sanctioned over 60 crore rupees in four instalments with an average of six crores per year. 
Table.1 Total funds received by the by NABARD for watershed development (1992-93 to 2017-18)

\begin{tabular}{|c|c|c|c|c|c|}
\hline $\begin{array}{c}\text { Sl. } \\
\text { No }\end{array}$ & Year & Receipts & Triennium & Advances & Triennium \\
\hline $\mathbf{1}$ & $92-93$ & 0.55 & & 0.37 & \\
\hline $\mathbf{2}$ & $93-94$ & 1.49 & 1.09 & 1.24 & 1.04 \\
\hline $\mathbf{3}$ & $94-95$ & 1.21 & 2.27 & 1.51 & 1.94 \\
\hline $\mathbf{4}$ & $95-96$ & 4.10 & 3.22 & 3.08 & 2.99 \\
\hline $\mathbf{5}$ & $96-97$ & 4.34 & 4.61 & 4.38 & 4.64 \\
\hline $\mathbf{6}$ & $97-98$ & 5.38 & 6.03 & 6.45 & 6.40 \\
\hline $\mathbf{7}$ & $98-99$ & 8.36 & 37.92 & 8.36 & 4.94 \\
\hline $\mathbf{8}$ & $99-00$ & 100.00 & 79.25 & 0.00 & 10.94 \\
\hline $\mathbf{9}$ & $00-01$ & 129.38 & 89.23 & 24.45 & 12.10 \\
\hline $\mathbf{1 0}$ & $01-02$ & 38.31 & 73.07 & 11.85 & 15.74 \\
\hline $\mathbf{1 1}$ & $02-03$ & 51.51 & 54.78 & 10.92 & 11.47 \\
\hline $\mathbf{1 2}$ & $03-04$ & 74.51 & 70.96 & 11.65 & 10.94 \\
\hline $\mathbf{1 3}$ & $04-05$ & 86.86 & 99.77 & 10.25 & 11.51 \\
\hline $\mathbf{1 4}$ & $05-06$ & 137.94 & 78.44 & 12.63 & 16.24 \\
\hline $\mathbf{1 5}$ & $06-07$ & 10.51 & 50.69 & 25.84 & 23.72 \\
\hline $\mathbf{1 6}$ & $07-08$ & 3.62 & 192.43 & 32.70 & 43.78 \\
\hline $\mathbf{1 7}$ & $08-09$ & 563.17 & 202.76 & 72.80 & 79.68 \\
\hline $\mathbf{1 8}$ & $09-10$ & 41.51 & 512.83 & 133.53 & 142.07 \\
\hline $\mathbf{1 9}$ & $10-11$ & 933.82 & 339.37 & 219.87 & 201.53 \\
\hline $\mathbf{2 0}$ & $11-12$ & 42.77 & 336.34 & 251.18 & 243.14 \\
\hline $\mathbf{2 1}$ & $12-13$ & 32.44 & 29.13 & 258.38 & 458.61 \\
\hline $\mathbf{2 2}$ & $13-14$ & 12.17 & 120.48 & 866.27 & 447.74 \\
\hline $\mathbf{2 3}$ & $14-15$ & 316.83 & 111.87 & 218.56 & 376.15 \\
\hline $\mathbf{2 4}$ & $15-16$ & 6.60 & 154.54 & 43.61 & 123.32 \\
\hline $\mathbf{2 5}$ & $16-17$ & 140.18 & 69.89 & 107.77 & 83.39 \\
\hline $\mathbf{2 6}$ & $17-18$ & 62.89 & & 98.80 & \\
\hline & Total & $\mathbf{2 8 1 0 . 4 6}$ & $\mathbf{2 7 2 0 . 9 4}$ & $\mathbf{2 4 3 6 . 4 6}$ & $\mathbf{2 3 3 4 . 0 1}$ \\
\hline Average & $\mathbf{1 0 8 . 0 9}$ & $\mathbf{1 1 3 . 3 7}$ & $\mathbf{9 3 . 7 1}$ & $\mathbf{9 7 . 2 5}$ \\
\hline Instability & $\mathbf{1 8 3 . 4 7}$ & & $\mathbf{3 5 . 1 2}$ & \\
\hline & & & & $\mathbf{1 6 2 . 9 2}$ & \\
\hline $\mathbf{1 5}$ & & & & \\
\hline $\mathbf{1 0}$ & & & & & \\
\hline & & & & & \\
\hline
\end{tabular}


Table.2 Total Grants received by NABARD from International Institutes between 1992-93 to 2017-18

\begin{tabular}{|c|c|c|c|}
\hline SI No & Year & Receipts & Triennium \\
\hline $\mathbf{1}$ & $92-93$ & 0.55 & \\
\hline $\mathbf{2}$ & $93-94$ & 1.63 & 1.26 \\
\hline $\mathbf{3}$ & $94-95$ & 1.6 & 2.47 \\
\hline $\mathbf{4}$ & $95-96$ & 4.19 & 3.75 \\
\hline $\mathbf{5}$ & $96-97$ & 5.45 & 5.36 \\
\hline $\mathbf{6}$ & $97-98$ & 6.45 & 6.75 \\
\hline $\mathbf{7}$ & $98-99$ & 8.36 & 8.60 \\
\hline $\mathbf{8}$ & $99-00$ & 10.98 & 14.64 \\
\hline $\mathbf{9}$ & $00-01$ & 24.59 & 15.40 \\
\hline $\mathbf{1 0}$ & $01-02$ & 10.64 & 14.74 \\
\hline $\mathbf{1 1}$ & $02-03$ & 8.98 & 9.63 \\
\hline $\mathbf{1 2}$ & $03-04$ & 9.26 & 8.84 \\
\hline $\mathbf{1 3}$ & $04-05$ & 8.28 & 9.05 \\
\hline $\mathbf{1 4}$ & $05-06$ & 9.62 & 11.40 \\
\hline $\mathbf{1 5}$ & $06-07$ & 16.31 & 11.80 \\
\hline $\mathbf{1 6}$ & $07-08$ & 9.46 & 16.35 \\
\hline $\mathbf{1 7}$ & $08-09$ & 23.27 & 24.99 \\
\hline $\mathbf{1 8}$ & $09-10$ & 42.23 & 38.09 \\
\hline $\mathbf{1 9}$ & $10-11$ & 48.77 & 42.18 \\
\hline $\mathbf{2 0}$ & $11-12$ & 35.54 & 41.53 \\
\hline $\mathbf{2 1}$ & $12-13$ & 40.29 & 31.49 \\
\hline $\mathbf{2 2}$ & $13-14$ & 18.64 & 28.68 \\
\hline $\mathbf{2 3}$ & $14-15$ & 27.12 & 18.80 \\
\hline $\mathbf{2 4}$ & $15-16$ & 10.64 & 15.77 \\
\hline $\mathbf{2 5}$ & $16-17$ & 9.56 & 10.14 \\
\hline $\mathbf{2 6}$ & $17-18$ & 10.22 & \\
\hline & Total & $\mathbf{4 0 2 . 6 3}$ & \\
\hline & Average & $\mathbf{1 5 . 4 9}$ & $\mathbf{1 6 . 3 2}$ \\
\hline & CAGR & $\mathbf{1 0 . 2 4}$ & \\
\hline & Instability & $\mathbf{8 5 . 9 8}$ & \\
\hline & & & \\
\hline
\end{tabular}


Table.3 Grants received by NABARD from KfW Germany

\begin{tabular}{|c|c|c|c|c|c|}
\hline SI No & Year & Receipts & Triennium & Advances & Triennium \\
\hline $\mathbf{1}$ & $92-93$ & 0.55 & - & 0.37 & - \\
\hline $\mathbf{2}$ & $93-94$ & 1.63 & 1.26 & 1.24 & 1.04 \\
\hline $\mathbf{3}$ & $94-95$ & 1.6 & 2.47 & 1.51 & 1.94 \\
\hline $\mathbf{4}$ & $95-96$ & 4.19 & 3.75 & 3.08 & 2.99 \\
\hline $\mathbf{5}$ & $96-97$ & 5.45 & 5.36 & 4.38 & 4.64 \\
\hline $\mathbf{6}$ & $97-98$ & 6.45 & 6.75 & 6.45 & 6.40 \\
\hline $\mathbf{7}$ & $98-99$ & 8.36 & 8.60 & 8.36 & 8.55 \\
\hline $\mathbf{8}$ & $99-00$ & 10.98 & 14.64 & 10.83 & 14.44 \\
\hline $\mathbf{9}$ & $00-01$ & 24.59 & 15.40 & 24.12 & 15.09 \\
\hline $\mathbf{1 0}$ & $01-02$ & 10.64 & 14.74 & 10.32 & 13.60 \\
\hline $\mathbf{1 1}$ & $02-03$ & 8.98 & 9.43 & 6.36 & 7.65 \\
\hline $\mathbf{1 2}$ & $03-04$ & 8.67 & 8.42 & 6.28 & 5.62 \\
\hline $\mathbf{1 3}$ & $04-05$ & 7.62 & 7.35 & 4.21 & 3.92 \\
\hline $\mathbf{1 4}$ & $05-06$ & 5.75 & 6.08 & 1.26 & 3.39 \\
\hline $\mathbf{1 5}$ & $06-07$ & 4.87 & 3.59 & 4.71 & 2.04 \\
\hline $\mathbf{1 6}$ & $07-08$ & 0.15 & - & 0.15 & - \\
\hline \multicolumn{2}{c|}{ Total } & $\mathbf{1 1 0 . 4 8}$ & $\mathbf{1 0 7 . 8 5}$ & $\mathbf{9 3 . 6 3}$ & $\mathbf{9 1 . 3 0}$ \\
\hline \multicolumn{2}{c|}{ Average } & $\mathbf{6 . 9 1}$ & $\mathbf{7 . 7 0}$ & $\mathbf{5 . 8 5}$ & $\mathbf{6 . 5 2}$ \\
\hline \multicolumn{2}{c}{ CAGR } & $\mathbf{3 . 0 8}$ & & $\mathbf{1 . 2 6}$ & \\
\hline \multicolumn{2}{|c|}{ Instability } & $\mathbf{8 1 . 0 4}$ & & $\mathbf{1 0 0 . 9 2}$ & \\
\hline
\end{tabular}

Table.4 Watershed Development Fund Project by NABARD and GOI 1999-00 to 2017-18

\begin{tabular}{|c|c|c|c|c|c|}
\hline SI No & Year & Receipts & Triennium & Advances & Triennium \\
\hline $\mathbf{1}$ & $99-00$ & 100.00 & & 0.00 & \\
\hline $\mathbf{2}$ & $00-01$ & 200.00 & 175.94 & 0.16 & 0.31 \\
\hline $\mathbf{3}$ & $01-02$ & 227.81 & 232.34 & 0.76 & 1.07 \\
\hline $\mathbf{4}$ & $02-03$ & 269.21 & 281.74 & 2.28 & 1.86 \\
\hline $\mathbf{5}$ & $03-04$ & 348.20 & 350.70 & 2.55 & 2.53 \\
\hline $\mathbf{6}$ & $04-05$ & 434.68 & 449.29 & 2.77 & 3.03 \\
\hline $\mathbf{7}$ & $05-06$ & 565.00 & 537.58 & 3.78 & 3.90 \\
\hline $\mathbf{8}$ & $06-07$ & 613.07 & 605.19 & 5.16 & 6.95 \\
\hline $\mathbf{9}$ & $07-08$ & 637.50 & 808.54 & 11.91 & 13.99 \\
\hline $\mathbf{1 0}$ & $08-09$ & 1175.04 & 1001.60 & 24.91 & 27.17 \\
\hline $\mathbf{1 1}$ & $09-10$ & 1192.25 & 1472.41 & 44.70 & 73.62 \\
\hline $\mathbf{1 2}$ & $10-11$ & 2049.95 & 1749.78 & 151.25 & 132.36 \\
\hline $\mathbf{1 3}$ & $11-12$ & 2007.15 & 1989.20 & 201.12 & 192.16 \\
\hline $\mathbf{1 4}$ & $12-13$ & 1910.50 & 1900.06 & 224.11 & 426.04 \\
\hline $\mathbf{1 5}$ & $13-14$ & 1782.52 & 1659.94 & 852.89 & 426.28 \\
\hline $\mathbf{1 6}$ & $14-15$ & 1286.79 & 1406.20 & 201.85 & 365.09 \\
\hline $\mathbf{1 7}$ & $15-16$ & 1149.28 & 1250.99 & 40.53 & 116.27 \\
\hline $\mathbf{1 8}$ & $16-17$ & 1316.90 & 1267.58 & 106.42 & 80.65 \\
\hline $\mathbf{1 9}$ & $17-18$ & 1336.55 & & 95.01 & \\
\hline \multicolumn{2}{|c|}{ Total } & $\mathbf{1 8 6 0 2 . 4 0}$ & $\mathbf{1 7 1 3 9 . 0 7}$ & $\mathbf{1 9 7 2 . 1 6}$ & $\mathbf{1 8 7 3 . 2 9}$ \\
\hline \multicolumn{2}{|c|}{ Average } & $\mathbf{9 7 9 . 0 7}$ & $\mathbf{1 0 0 8 . 1 8}$ & $\mathbf{1 0 3 . 8 0}$ & $\mathbf{1 1 0 . 1 9}$ \\
\hline \multicolumn{2}{|c|}{ CAGR } & $\mathbf{1 1 . 5 8}$ & & $\mathbf{3 9 . 7 7}$ & \\
\hline Instability & $\mathbf{4 1 . 8 8}$ & & $\mathbf{1 3 4 . 3 3}$ & \\
\hline & & & & & \\
\hline
\end{tabular}


Table.5 Indo German Watershed Development Programme - Andhra Pradesh

\begin{tabular}{|c|c|c|c|c|c|}
\hline $\begin{array}{c}\text { SI } \\
\text { No }\end{array}$ & Year & Receipts & Triennium & Advances & Triennium \\
\hline $\mathbf{1}$ & $03-04$ & 0.58 & & 0.27 & \\
\hline $\mathbf{2}$ & $04-05$ & 0.33 & 0.42 & 0.50 & 0.26 \\
\hline $\mathbf{3}$ & $05-06$ & 0.35 & 0.50 & 0.00 & 0.33 \\
\hline $\mathbf{4}$ & $06-07$ & 0.83 & 0.87 & 0.50 & 0.58 \\
\hline $\mathbf{5}$ & $07-08$ & 1.42 & 1.89 & 1.24 & 1.78 \\
\hline $\mathbf{6}$ & $08-09$ & 3.42 & 2.75 & 3.60 & 2.88 \\
\hline $\mathbf{7}$ & $09-10$ & 3.41 & 6.16 & 3.79 & 6.35 \\
\hline $\mathbf{8}$ & $10-11$ & 11.65 & 7.64 & 11.65 & 7.77 \\
\hline $\mathbf{9}$ & $11-12$ & 7.87 & 10.18 & 7.88 & 10.19 \\
\hline $\mathbf{1 0}$ & $12-13$ & 11.03 & 8.54 & 11.04 & 8.55 \\
\hline $\mathbf{1 1}$ & $13-14$ & 6.72 & 8.03 & 6.74 & 8.04 \\
\hline $\mathbf{1 2}$ & $14-15$ & 6.33 & 5.12 & 6.35 & 5.04 \\
\hline $\mathbf{1 3}$ & $15-16$ & 2.32 & 3.17 & 2.03 & 2.80 \\
\hline $\mathbf{1 4}$ & $16-17$ & 0.86 & 1.59 & 0.03 & 1.03 \\
\hline \multicolumn{2}{|c|}{ Total } & $\mathbf{5 7 . 1 2}$ & $\mathbf{5 6 . 8 7}$ & $\mathbf{5 5 . 6 2}$ & $\mathbf{5 5 . 6 1}$ \\
\hline Average & $\mathbf{4 . 0 8}$ & $\mathbf{4 . 3 7}$ & $\mathbf{3 . 9 7}$ & $\mathbf{4 . 2 8}$ \\
\hline CAGR & $\mathbf{1 9 . 5 5}$ & & $\mathbf{6 3 . 1 1}$ & \\
\hline Instability & $\mathbf{7 8 . 2 3}$ & & $\mathbf{8 5 . 4 5}$ & \\
\hline
\end{tabular}

Table.6 Indo German Watershed Development Programme - Maharashtra

\begin{tabular}{|c|c|c|c|c|c|}
\hline SI No & Year & Receipts & Triennium & Advances & Triennium \\
\hline $\mathbf{1}$ & $05-06$ & 3.17 & - & 3.23 & - \\
\hline $\mathbf{2}$ & $06-07$ & 9.32 & 4.59 & 9.78 & 6.15 \\
\hline $\mathbf{3}$ & $07-08$ & 1.28 & 8.99 & 5.45 & 9.87 \\
\hline $\mathbf{4}$ & $08-09$ & 16.37 & 16.10 & 14.38 & 16.37 \\
\hline $\mathbf{5}$ & $09-10$ & 30.65 & 24.96 & 29.29 & 25.03 \\
\hline $\mathbf{6}$ & $10-11$ & 27.85 & 25.77 & 31.42 & 26.53 \\
\hline $\mathbf{7}$ & $11-12$ & 18.8 & 20.46 & 18.87 & 21.26 \\
\hline $\mathbf{8}$ & $12-13$ & 14.72 & - & 13.48 & 11.09 \\
\hline $\mathbf{9}$ & $13-14$ & 0.00 & - & 0.93 & 4.87 \\
\hline $\mathbf{1 0}$ & $14-15$ & 0.00 & - & 0.2 & 0.45 \\
\hline $\mathbf{1 1}$ & $15-16$ & 0.00 & - & 0.21 & 0.18 \\
\hline $\mathbf{1 2}$ & $16-17$ & 0.00 & - & 0.13 & - \\
\hline \multicolumn{7}{|c|}{ Total } & $\mathbf{1 2 2 . 1 6}$ & $\mathbf{1 0 0 . 8 6}$ & $\mathbf{1 2 7 . 3 7}$ & $\mathbf{1 2 1 . 8 0}$ \\
\hline \multicolumn{2}{|c|}{ Average } & $\mathbf{1 5 . 2 7}$ & $\mathbf{1 6 . 8 1}$ & $\mathbf{1 0 . 6 1}$ & $\mathbf{1 2 . 1 8}$ \\
\hline \multicolumn{2}{|c|}{ CAGR } & $\mathbf{3 3 . 2 7}$ & & $\mathbf{- 3 1 . 8 3}$ & \\
\hline
\end{tabular}


Table.7 Indo German Watershed Development Programme - Gujarat

\begin{tabular}{|c|c|c|c|c|c|}
\hline SI No & Year & Receipts & Triennium & Advances & Triennium \\
\hline $\mathbf{1}$ & $06-07$ & 0.37 & - & 0.14 & - \\
\hline $\mathbf{2}$ & $07-08$ & 0.93 & 0.77 & 0.43 & 0.60 \\
\hline $\mathbf{3}$ & $08-09$ & 1.01 & 1.36 & 1.23 & 1.36 \\
\hline $\mathbf{4}$ & $09-10$ & 2.14 & 2.20 & 2.42 & 2.46 \\
\hline $\mathbf{5}$ & $10-11$ & 3.46 & 3.71 & 3.74 & 3.91 \\
\hline $\mathbf{6}$ & $11-12$ & 5.53 & 5.23 & 5.56 & 5.33 \\
\hline $\mathbf{7}$ & $12-13$ & 6.69 & 5.89 & 6.7 & 5.90 \\
\hline $\mathbf{8}$ & $13-14$ & 5.44 & 7.55 & 5.44 & 7.43 \\
\hline $\mathbf{9}$ & $14-15$ & 10.51 & 6.74 & 10.16 & 5.48 \\
\hline $\mathbf{1 0}$ & $15-16$ & 4.28 & 5.48 & 0.83 & 4.06 \\
\hline $\mathbf{1 1}$ & $16-17$ & 1.65 & 2.20 & 1.2 & 1.92 \\
\hline $\mathbf{1 2}$ & $17-18$ & 0.68 & - & 3.74 & - \\
\hline \multicolumn{2}{|c|}{ Total } & $\mathbf{4 2 . 6 9}$ & $\mathbf{4 1 . 1 3}$ & $\mathbf{4 1 . 5 9}$ & $\mathbf{3 8 . 4 6}$ \\
\hline Average & $\mathbf{6 . 5 7}$ & $\mathbf{7 . 4 8}$ & $\mathbf{6 . 4 0}$ & $\mathbf{6 . 9 9}$ \\
\hline CAGR & $\mathbf{1 1 . 6 4}$ & & $\mathbf{1 9 . 5 6}$ & \\
\hline \multicolumn{2}{|c|}{ Instability } & $\mathbf{7 4 . 6 5}$ & & $\mathbf{1 7 . 8 0}$ & \\
\hline \multicolumn{2}{|r|}{}
\end{tabular}

Table.8 Indo German Watershed Development Programme - Rajasthan

\begin{tabular}{|c|c|c|c|c|c|}
\hline SI No & Year & Receipts & Triennium & Advances & Triennium \\
\hline $\mathbf{1}$ & $07-08$ & 0.9 & - & 1.17 & - \\
\hline $\mathbf{2}$ & $08-09$ & 0.7 & 1.37 & 1.75 & 3.29 \\
\hline $\mathbf{3}$ & $09-10$ & 2.51 & 1.72 & 6.94 & 4.44 \\
\hline $\mathbf{4}$ & $10-11$ & 1.94 & 2.56 & 4.62 & 6.41 \\
\hline $\mathbf{5}$ & $11-12$ & 3.24 & 4.30 & 7.67 & 10.18 \\
\hline $\mathbf{6}$ & $12-13$ & 7.71 & 5.34 & 18.25 & 12.63 \\
\hline $\mathbf{7}$ & $13-14$ & 5.06 & 7.50 & 11.96 & 17.75 \\
\hline $\mathbf{8}$ & $14-15$ & 9.73 & 5.98 & 23.04 & 14.15 \\
\hline $\mathbf{9}$ & $15-16$ & 3.15 & 5.64 & 7.45 & 11.69 \\
\hline $\mathbf{1 0}$ & $16-17$ & 4.04 & 3.45 & 4.58 & 8.20 \\
\hline $\mathbf{1 1}$ & $17-18$ & 3.15 & - & 12.56 & - \\
\hline \multicolumn{2}{|c|}{ Total } & 42.13 & 37.85 & 99.99 & 88.73 \\
\hline \multicolumn{2}{|c|}{ Average } & 3.83 & 4.21 & 9.09 & 9.86 \\
\hline \multicolumn{2}{|c|}{ CAGR } & $\mathbf{1 7 . 3 8}$ & & $\mathbf{1 9 . 4 9}$ & \\
\hline Instability & $\mathbf{5 5 . 5 9}$ & & $\mathbf{5 6 . 9 7}$ & \\
\hline \multicolumn{2}{|r|}{} \\
\hline
\end{tabular}


Table.9 Watershed Programmes implemented under Rashtriya Sam Vikas Yojana (RSVY)

\begin{tabular}{|c|c|c|c|c|c|}
\hline SI No & Year & Receipts & Triennium & Advances & Triennium \\
\hline $\mathbf{1}$ & $04-05$ & 10.00 & & 0.00 & \\
\hline $\mathbf{2}$ & $05-06$ & & 10.00 & 0.58 & 0.33 \\
\hline $\mathbf{3}$ & $06-07$ & & 0.00 & 0.4 & 0.86 \\
\hline $\mathbf{4}$ & $07-08$ & & 14.42 & 1.59 & 1.90 \\
\hline $\mathbf{5}$ & $08-09$ & 14.42 & 14.42 & 3.72 & 4.64 \\
\hline $\mathbf{6}$ & $09-10$ & & 19.71 & 8.62 & 11.04 \\
\hline $\mathbf{7}$ & $10-11$ & 25.00 & 17.79 & 20.79 & 15.72 \\
\hline $\mathbf{8}$ & $11-12$ & 10.58 & 17.79 & 17.74 & 13.86 \\
\hline $\mathbf{9}$ & $12-13$ & & 10.58 & 3.05 & 7.02 \\
\hline $\mathbf{1 0}$ & $13-14$ & & & 0.28 & \\
\hline \multicolumn{2}{|c|}{ Total } & $\mathbf{6 0 . 0 0}$ & $\mathbf{1 0 4 . 7 1}$ & $\mathbf{5 6 . 7 7}$ & $\mathbf{5 5 . 3 7}$ \\
\hline \multicolumn{2}{|c|}{ Average } & $\mathbf{6 . 0 0}$ & $\mathbf{1 3 . 0 9}$ & $\mathbf{5 . 6 8}$ & $\mathbf{6 . 9 2}$ \\
\hline \multicolumn{2}{|c|}{ CAGR } & - & & $\mathbf{1 7 . 6 0}$ & \\
\hline
\end{tabular}

Table.10 Loans issued by NABARD for Watershed Development

\begin{tabular}{|c|c|c|c|}
\hline SI No & Year & Amount & Triennium \\
\hline $\mathbf{1}$ & $04-05$ & 1.96 & 4.55 \\
\hline $\mathbf{2}$ & $05-06$ & 5.00 & 6.12 \\
\hline $\mathbf{3}$ & $06-07$ & 6.70 & 9.36 \\
\hline $\mathbf{4}$ & $07-08$ & 6.65 & 16.91 \\
\hline $\mathbf{5}$ & $08-09$ & 14.72 & 25.39 \\
\hline $\mathbf{6}$ & $09-10$ & 29.36 & 32.57 \\
\hline $\mathbf{7}$ & $10-11$ & 32.10 & 36.51 \\
\hline $\mathbf{8}$ & $11-12$ & 36.25 & 38.51 \\
\hline $\mathbf{9}$ & $12-13$ & 41.18 & 40.24 \\
\hline $\mathbf{1 0}$ & $13-14$ & 38.10 & 39.84 \\
\hline $\mathbf{1 1}$ & $14-15$ & 41.45 & 39.63 \\
\hline $\mathbf{1 2}$ & $15-16$ & 39.97 & 37.04 \\
\hline $\mathbf{1 3}$ & $16-17$ & 37.47 & \\
\hline $\mathbf{1 4}$ & $17-18$ & 33.69 & $\mathbf{3 2 6 . 6 8}$ \\
\hline & Total & $\mathbf{3 6 4 . 6 0}$ & $\mathbf{2 7 . 2 2}$ \\
\hline & Average & $\mathbf{2 6 . 0 4}$ & \\
\hline & CAGR & $\mathbf{2 2 . 9 2}$ & $\mathbf{1 3 . 0 4}$ \\
\hline
\end{tabular}


Table.11 Watershed Development Promotional Activities

\begin{tabular}{|c|c|c|c|}
\hline $\begin{array}{c}\text { SI } \\
\text { No }\end{array}$ & Year & Amount & Triennium \\
\hline $\mathbf{1}$ & $00-01$ & 0.16 & \\
\hline $\mathbf{2}$ & $01-02$ & 0.76 & 1.07 \\
\hline $\mathbf{3}$ & $02-03$ & 2.28 & 1.86 \\
\hline $\mathbf{4}$ & $03-04$ & 2.55 & 2.53 \\
\hline $\mathbf{5}$ & $04-05$ & 2.77 & 3.03 \\
\hline $\mathbf{6}$ & $05-06$ & 3.78 & 3.90 \\
\hline $\mathbf{7}$ & $06-07$ & 5.16 & 6.95 \\
\hline $\mathbf{8}$ & $07-08$ & 11.91 & 13.99 \\
\hline $\mathbf{9}$ & $08-09$ & 24.91 & 27.17 \\
\hline $\mathbf{1 0}$ & $09-10$ & 44.7 & 23.24 \\
\hline $\mathbf{1 1}$ & $10-11$ & 0.1 & \\
\hline & Total & $\mathbf{9 9 . 0 8}$ & \\
\hline & Average & $\mathbf{9 . 0 1}$ & \\
\hline & CAGR & $\mathbf{2 5 . 3 2}$ & \\
\hline & Instability & $\mathbf{1 0 3 . 3 7}$ \\
\hline
\end{tabular}

Fig.1 Trends in the grants received and advances made by NABARD

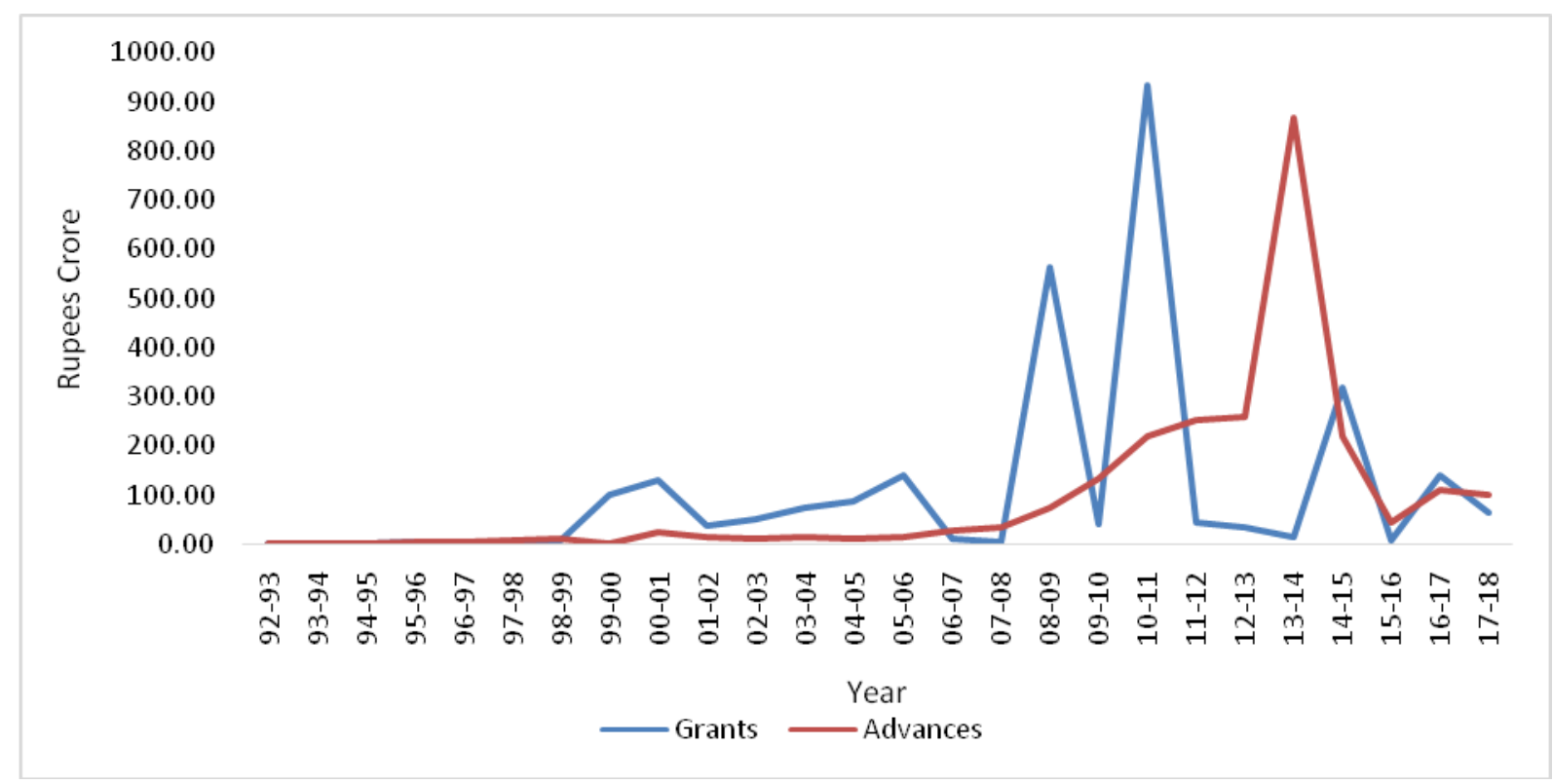

Out of the total sanctioned amount,56.77 crore amount was disbursed with an average of 4.06 crore between 2005-06 and 2013-14.

Apart from all these schemes implemented by NABARD with the help of other agencies, it also provided loans to its constituent banks for watershed development work (Table 10). NABARD has started lending with the sum of Rs. 1.96 crores in 2004-05,until 2017-18 bank has financed around 364.60 crore rupees. The amount was disbursed with an average of 
26.04 crores annually and it has the annual growth rate of 27.34 percent over the period.

NABARD has also equally taken effort for promoting the watershed activities at the farmers level throughout the country (Table 11). It has promoted watershed activities from 2001-02 till 2010-11, in this period National Bank has expensed about 99.09 crore rupees for promotional activities with an average of Rs. 9.01 crores annually. Amount spent on promotional activities were increased at the rate of 25.32 per cent annually and the flow of funds was unstable or highly volatile (103.37\%

NABARD has implemented 4 different projects for developing the dry land areas in support with the International agencies and GoI. It has also advanced the loans of about 364.59 crores and has played a responsible role in managing dry land area with the various watershed schemes. Even though the rate of grants received is higher, consistency is very low. Since this kind of activities needs huge investment there should be consistency in the funds' flow, and breaking the continuity in implementation may cause damage to the structures on the field. Hence, the Government should give continuous priority to these sectors without volatility in the flow of funds. The study indicates that whenever there was a drought in the country, the stress for the watershed development work has been increased. It indicates that there were no precautionary measures taken by the governments. There are lot many lessons to learn from the past, Government should give emphasis to the Science and Technology which can advise the Government at the earliest so that the government can take precautions before the damage occurs.

\section{References}

Deng, N., Ling, X., Sun, Y., Zhang, C., Fahad,
S., Peng, S., Cui, K., Nie, L., and Huang, J. 2015. Influence of temperature and solar radiation on grain yield and quality in irrigated rice system. Europ. J. Agron. 64: 37 - 46.

Kotru, R. 2003. Watershed management experiences in GTZ-supported projects in India. Achouri, M., Tennyson, L., Kumar, U., and Roger, W. (eds.) In: Preparing for the next generation of watershed management programmes and projects, Asia. Proceedings of the Asian Regional Workshop, Kathmandu, Nepal. pp 85-91.

Lal, M. 2003. Global climate change: India's monsoon and its variability. $J$. Environmental Studies Policy. 6 (1): 134.

Lokesh, S. and Poddar, R. S. 2016. Monsoon failure and drought situation in 2012: A case study of Vijayapura district. $J$. Farm Sci., 29(2): 231-234.

Lokesh, S. and Poddar R. S. 2018. Impact of Drought on Water Resources and Agriculture in Karnataka. Int. J. Pure App. Biosci. 6 (2): 1102-1107.

Rossi, G. and Castiglione, L. 2011. Towards guidelines for drought preparedness and mitigation planning within EU water policy. European Water, 36: 3751.

Tirlapur, L. N., Desai. N. R. M., and Basavaraja, H. 2015. Impact of rainfall variability on agriculture in North Karnataka. Karnataka J. Agric. Sci. 28(5): 753 - 759.

Udmale, P., Ichikawa, Y., Manandhar, S., Ishidaira, H., and Kiem A. S. 2014. Farmers' perception of drought impacts, local adaptation and administrative mitigation measures in Maharashtra State, India. Int. J. Disaster Risk Red., 10: 250-269.

Verma, R. R., Srivastava, T. K. \& Singh, P. Climate change impacts on rainfall and temperature in sugarcane growing 
Upper Gangetic Plains of India (online). Theor Appl Climatol. Available: https://doi.org/10.1007/s00704-0182378-8.

Vijayalakshmi, C., Radhakrishnan, R., Nagarajan, M., and Rajendran, C. 1991. Effect of Solar Radiation Deficit on Rice Productivity. J. Agron. Crop Sci. 167, 184-187.

Vining K. C. 1990. Effects of weather on agricultural crops and livestock: an overview, International Journal of Environmental Studies, 36:1-2, 27-39. Zhang, X., Obringer, R., Wei, C., Chen, N., and Niyogi, D. 2017. Droughts in India from 1981 to 2013 and Implications to Wheat Production (online). Scientific Reports. 7:44552. Available: https://www.ncbi.nlm.nih.gov/pmc/arti cles/PMC5353643/pdf/srep44552.pdf.

\section{How to cite this article:}

Lokesh, S. and Indira Devi, P. 2019. Instability and Growth Rate Analysis of Investments done by NABARD in the Watershed Development Sector of India. Int.J.Curr.Microbiol.App.Sci. 8(11): 2661-2674. doi: https://doi.org/10.20546/ijcmas.2019.811.305 